DOI: https://doi.org/10.47405/mjssh.v7i1.1248

\begin{tabular}{|c|c|}
\hline$\sum_{i=1}$ & Malaysian Journal of Social Sciences and Humanities (MJSSH) \\
\hline $\begin{array}{l}\text { Malaysian Journal of } \\
\text { Solcial cciences and }\end{array}$ & Volume 7, Issue 1, January 2022 \\
\hline (MJ-SSH) & e-ISSN : 2504-8562 \\
\hline & $\begin{array}{l}\text { Journal home page: } \\
\text { www.msocialsciences.com }\end{array}$ \\
\hline
\end{tabular}

\title{
Modul Pemikiran Sains Keusahawanan Untuk Pelajar Tahun Lima Dalam Pendidikan STEM
}

\author{
Jamilah Ahmad ${ }^{1}$, Siew Nyet Moi ${ }^{1}$ \\ 1Fakulti Psikologi dan Pendidikan, Universiti Malaysia Sabah (UMS), Sabah, Malaysia
}

Correspondence: Siew Nyet Moi (sopiah@ums.edu.my)

\begin{abstract}
Abstrak
Kajian ini dijalankan untuk i) menentukan kesahan, kebolehpercayaan, kebolehlaksanaan modul berasaskan pendekatan isu sosiosaintifik berbantukan peta pemikiran roda (PISPP), dan ii) menilai kesannya terhadap pemikiran sains keusahawanan pelajar tahun lima dalam pendidikan STEM. Fasa pertama kesahan modul dilakukan dengan menggunakan khidmat lima orang pakar penilai dan 30 orang pelajar tahun lima. Data diperoleh melalui maklum balas responden dalam soal selidik 5 poin skala Likert dan ujian Pemikiran Sains Keusahawanan. Fasa kedua adalah penilaian melalui reka bentuk kajian kuasi eksperimental dengan Ujian Pra-Pasca Kumpulan Kawalan Tidak Setara. Seramai 60 orang pelajar tahun lima yang terbahagi kepada dua kumpulan iaitu kumpulan PISPP $(n=30)$ dan kumpulan kawalan $(n=30)$. Keputusan penilaian modul PISPP menunjukkan nilai kesahan yang baik dan kebolehpercayaan alfa Cronbach yang boleh diterima iaitu antara .74 dan .89 dengan nilai keseluruhan .92. Pelajar menunjukkan tahap penerimaan yang tinggi $(\mathrm{m}=4.53)$ terhadap aktiviti-aktiviti dalam Modul PISPP. Respon secara lisan menunjukkan kesesuaian dan penerimaan modul dalam kalangan pelajar. Dapatan ujian-t tak bersandaran membuktikan kesan positif yang signifikan terhadap kelima-lima konstruk dalam pemikiran sains keusahawanan. Tuntasnya, kesemua dapatan ini menunjukkan bahawa Modul PISPP menyediakan satu modul pengajaran dan pembelajaran STEM yang sah, boleh dipercayai dan dilaksanakan, dan berkesan dalam meningkatkan pemikiran sains keusahawanan bagi pelajar tahun lima.
\end{abstract}

Kata kunci: pembangunan modul, penilaian modul, pendekatan isu sosiosaintifik, peta pemikiran roda, pemikiran sains keusahawanan, pendidikan STEM

\section{An Entrepreneurial Science Thinking Module for Year Five Students in STEM Education}

\begin{abstract}
This research was conducted to i) establish the validity, reliability and feasibility of the module based on the socioscientific issues approach aided by the thinking wheel map (PISPP), and ii) evaluate its effects on the science entreprenuriel thinking among fifth graders in STEM education. The first phase of the module evaluation was conducted by five expert evaluators and among 30 fifth graders. Data was collected via respondents' feedback in the 5-point Likert scale questionnaire and a science entrepreneurial thinking test. The second phase was evaluation through the quasi-experimental research design with the pre-test post-test control group design. 60 fifth graders were gathered into two groups which were the PISPP group $(n=30)$ and control group $(n=30)$. The results of the PISPP module evaluation shows that the validity value was good and the alpha cronbach reliability was between .74
\end{abstract}


and .89 with the overall value of .92 . The students showed a high level of acceptance $(m=4.53)$ towards the activities in the PISPP Module. Feedback from the students showed the module's feasibility and acceptance by students. The results of the t-test proves a significantly positive effect on the five constructs in entreprenuerial science thinking. Therefore, these findings establish that the PISPP teaching and learning module is valid, reliable, feasible and effective in increasing fifth graders' entreprenuerial science thinking in STEM education.

Keywords: socioscientific issues approach, thinking wheel map, entreprenuerial science thinking, STEM education

\section{Pengenalan}

Bersandar pada hakikat bahawa penyediaan modal insan yang berfikiran kritikal, mampu mencipta idea yang kreatif dan inovatif serta mempunyai nilai etika yang tinggi perlu dihasilkan, pemikiran keusahawanan mula mendapat perhatian dan dikesan sebagai salah satu aspek kemahiran yang perlu dikuasai oleh pelajar bagi mendepani masa hadapan yang kian mencabar (Bacigalupo et al., 2016; Buang et al., 2009). Pemikiran keusahawanan bukanlah satu kemahiran yang perlu dikuasai untuk menjadi usahawan semata-mata, tetapi ia adalah satu kemahiran insaniah yang penting dalam mengukuhkan pembangunan kemanusiaan, memenuhi pasaran kerja dan meningkatkan persaingan (Bacigalupo et al., 2016).

Pemikiran sains keusahawanan sebenarnya bukanlah satu konsep yang ingin melahirkan usahawan semata-mata. Pemikiran sains keusahawanan adalah suatu kemahiran berfikir reka bentuk yang berlandaskan pengetahuan sains dan orientasi keusahawanan (Buang et al., 2009). Dalam mereka bentuk sesuatu model ciptaan, pelajar perlu menguasai lima konstruk penting dalam pemikiran sains keusahawanan ini iaitu pemerhatian, idea baharu, inovasi, kreativiti dan nilai (Buang et al., 2009). Penguasaan konstruk ini akan membantu pelajar dalam menjana idea, memilih idea, melakar reka bentuk, menghasilkan model ciptaan dan menilai sumbangan hasil penciptaan dalam masyarakat.

Bertitik tolak daripada kesedaran ini, timbul keperluan yang tinggi terhadap perlunya penerapan pemikiran keusahawanan ini dalam kurikulum (Saavedra \& Opfer, 2012). Seperti negara-negara lain, Malaysia kini sedang menyediakan pelajar-pelajar di sekolah dengan keperluan global dunia. Dalam Kurikulum Standard Sekolah Rendah (KSSR) Semakan 2017, elemen merentas kurikulum keusahawanan diterapkan dalam semua mata pelajaran termasuklah Sains. Ironinya, pembangunan modul yang dapat memupuk pemikiran sains keusahawanan dalam pendidikan STEM di sekolah rendah masih amat terhad dan terbatas. Walhal, Karlsson et al. (2021) menekankan bahawa penekanan inovasi dan keusahawanan adalah sangat signifikan dalam menghadapi abad ke-21 ini.

Lantas, satu konsep pembelajaran yang mengintegrasikan STEM, inovasi dan keusahawanan dalam kurikulum sekolah perlu diperkenalkan agar pelajar yang dihasilkan berupaya untuk mereka cipta, berinovasi dan mempunyai nilai keusahawanan sekali gus dapat memenuhi kriteria modal insan yang diharapkan menjelang tahun 2030. Malah, penerapan elemen keusahawanan dalam pendidikan STEM juga adalah sebagai salah satu usaha untuk menarik minat pelajar menceburi bidang STEM di samping mereka belajar mengkomersialkan idea hasil daripada pengintegrasian semua bidang.

Lantaran masih wujud jurang dan kekangan dalam pelaksanaan penerapan pemikiran sains keusahawanan dalam kurikulum, pembelajaran STEM berasaskan pendekatan isu sosiosaintifik berbantukan peta pemikiran roda (PISPP) dibangunkan dan seterusnya kesannya terhadap pemikiran sains keusahawanan dalam Pendidikan STEM ditentukan. Keperluan kajian ini adalah selari dengan keperluan dasar Pelan Pembangunan Pendidikan Malaysia (PPPM 2013-2025) yang menggalakkan penerapan Elemen Merentas Kurikulum (EMK) keusahawanan dalam PdP (Kementerian Pendidikan Malaysia, 2012). 


\section{Kerangka Teoretikal}

Reka bentuk dan pembangunan modul pengajaran dan pembelajaran STEM berasaskan pendekatan isu sosiosaintifik dan peta pemikiran roda ini dibuat berdasarkan analisis pelbagai elemen seperti konteks pendekatan isu sosiosaintifik, penggunaan peta pemikiran roda, pelaksanaan pembelajaran STEM di sekolah rendah, pemahaman tentang gaya pembelajaran pelajar sekolah rendah serta hubung kaitnya dengan teori dan model pengajaran. Oleh sebab tumpuan modul ini adalah kepada pelajar tahun lima di sekolah rendah, maka modul ini mengaplikasikan konsep pembinaan pengetahuan melalui adaptasi dengan persekitaran mengikut Teori Konstruktivisme Kognitif Piaget (1976) dan berlandaskan Zon Perkembangan Proksimal mengikut Teori Konstruktivisme Sosial Vygotsky (1978).

Sesuai dengan responden pelajar tahun lima dalam kajian ini, Teori Konstruktivisme Kognitif Piaget menekankan konsep di mana pelajar menggunakan pengetahuan lepas mereka untuk mengupas isu sosiosaintifik yang diberikan dan mereka cipta produk yang dapat menyelesaikan isu tersebut. Melalui perbincangan dan penyelesaian isu sosiosaintifik, pelajar akan melalui penerokaan dan mengenal pasti pengetahuan sedia ada (skema) mereka. Impaknya, akan berlaku keseimbangan antara proses asimilasi dan akomodasi terhadap maklumat baharu berdasarkan kepada pengetahuan sedia ada mereka (Sjøberg, 2007).

Selaras dengan tahap umur pelajar tahun lima (10 hingga 11 tahun) ini juga, teori konstruktivisme Kognitif Piaget ini menjelaskan bahawa kanak-kanak ini berada pada tahap operasi konkrit di mana pelajar mampu untuk melakukan proses penyiasatan yang rasional dan penyelesaian masalah yang bersifat konkrit (Pascual-Leone \& Johnson, 2005). Justeru, dalam kajian ini, pelajar diberikan bahan rangsangan seperti isu sosiosaintifik dan rangsangan bergambar bagi disesuaikan dengan tahap kognitif pelajar. Tambahan lagi, selaras dengan teori kontruktivisme Sosial Vygotsky, kajian ini melibatkan pembahagian pelajar dalam kumpulan-kumpulan kecil bagi memudahkan mereka melakukan aktiviti sumbang saran dan penjanaan idea. Aktiviti perbincangan dalam kumpulan kecil secara tidak langsung menerapkan aspek sosial ke dalam pembelajaran pelajar (Jones \& Brader-Araje, 2002).

Pengkaji juga menyedari kepentingan prinsip pedagogi dalam proses pengajaran dan pembelajaran di sekolah rendah bagi menyokong proses pembinaan maklumat dan pengetahuan secara kognitif dan sosial. Kajian ini menggunakan Model Pembelajaran Pemikiran Sains Keusahawanan (Buang et al., 2009), Model Pendekatan Isu Sosiosaintifik (Sadler et al., 2017) dan peta pemikiran roda (Bloom (1956; Glenn (1972); Bengston, 2016) dalam pembinaan modul (Rajah 1).

Model PIS ini diguna pakai kerana kesesuaiannya dengan psikologi, sosial dan pertumbuhan emosi kanak-kanak serta kebolehlaksanaannya dalam pelbagai aspek Pendidikan Sains (Zeidler \& Nichols, 2009). Guru yang menggunakan PIS dalam sesi pembelajaran dapat membantu pelajar untuk mengembangkan dan menilai hujah berkaitan isu-isu semasa (Owens et al., 2017). Fasa pertama adalah tertumpu kepada perbincangan isu yang diutarakan. Dalam fasa ini, pelajar membina kefahaman dengan menghubungkan isu dengan idea sains dan kepekaan masyarakat. Fasa kedua pula menyediakan landasan kepada guru untuk menggalakkan pelajar memahami dan mengamalkan sains yang menitikberatkan isu sosiosaintifik dan menaakul komponen masyarakat dalam isu sosiosaintifik. Dalam hal ini, pelajar akan melibatkan diri secara aktif dalam mencari pertemuan antara isu sosial, pengetahuan sains serta amalan sains dan saintifik bagi menjadikan isu lebih relevan untuk diselesaikan (Sadler et al., 2017). Fasa terakhir adalah fasa yang menggalakkan pelajar untuk mensintesis idea dan amalan. Fasa ini menyediakan peluang bagi pelajar untuk melibatkan diri secara aktif dalam menzahirkan idea dan pendapat secara beretika.

Melalui kajian yang dijalankan oleh Birmingham dan Barton (2014) serta Nam dan Chen (2017), pendekatan isu sosiosaintifik (PIS) kini menjadi pendekatan pilihan dalam menyelesaikan isu sains, teknologi dan masyarakat. PIS dilihat dapat membantu meningkatkan pengetahuan saintifik pelajar (Driver et al., 2000; Kinslow \& Sadler, 2018; Sadler et al., 2017; Topçu et al., 2018). Pengetahuan saintifik yang dijana melalui perdebatan isu sosiosaintifik yang berlaku akan menggalakkan pelajar 
DOI: https://doi.org/10.47405/mjssh.v7i1.1248

untuk menjana idea dengan lebih berkesan kerana mereka perlu mengaitkan hasil sumbangan penciptaan mereka kepada penyelesaian masalah dalam masyarakat.

Rajah 1: Kerangka teoretikal dalam reka bentuk dan pembangunan Modul Pembelajaran PISPP

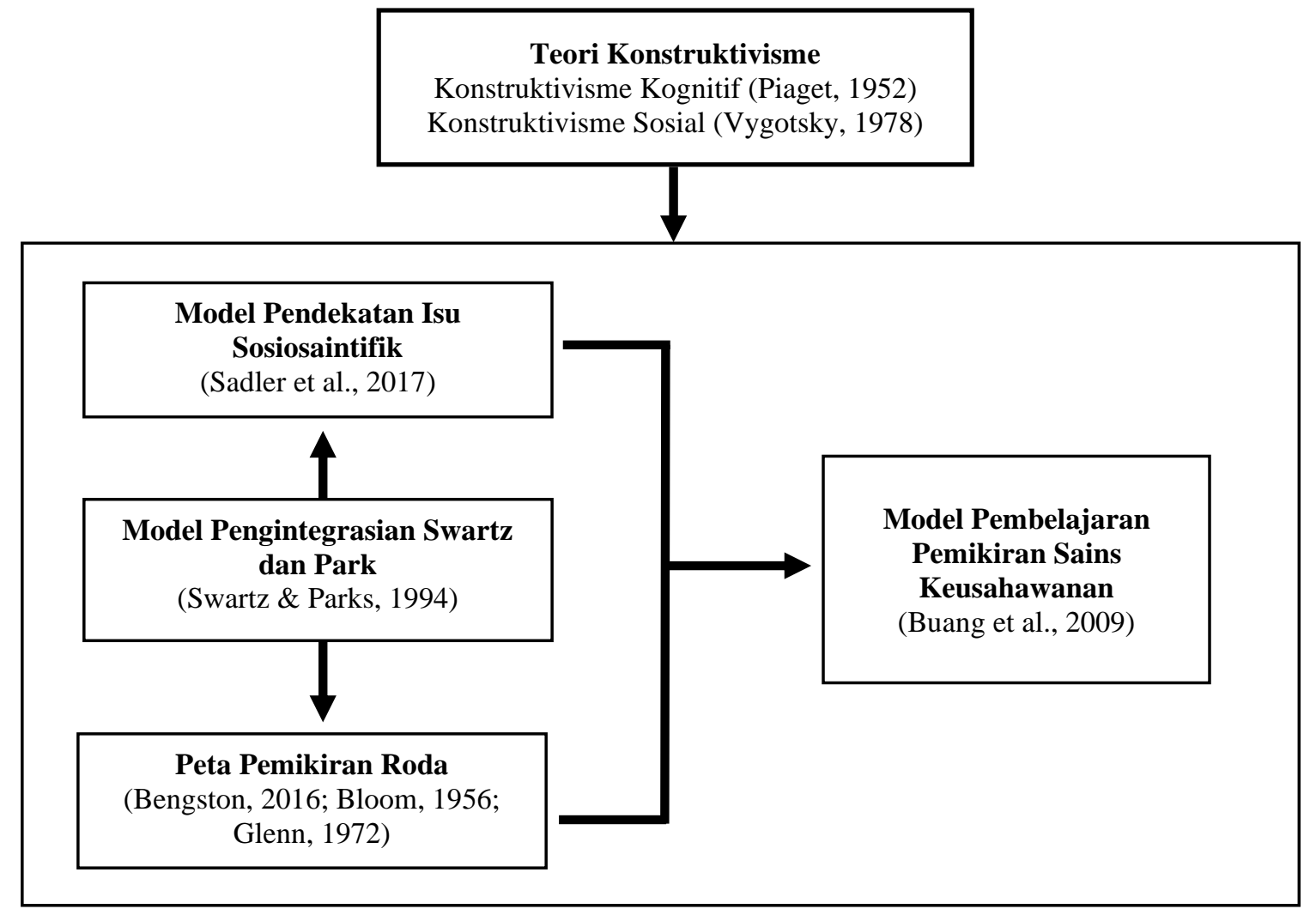

Peta Pemikiran Roda diadaptasi daripada Bloom (1956), Glenn (1972) dan Bengston (2016). Dalam PP roda ini, peta akan dibahagikan kepada pusat kitaran dan lima kitaran yang akan membantu pelajar menjana dan mengorganisasikan idea mereka. Semasa penggunaan modul ini, pelajar akan diberi isu sosiosaintifik untuk dibincangkan dan dihujahkan. Pada masa ini, apa-apa sahaja idea penghujahan yang logik dan saintifik akan ditulis pada pusat peta. Idea-idea ini yang akan menjadi pencetus idea kepada pelajar untuk diselesaikan dalam kitaran seterusnya. Bengston (2016) menyatakan bahawa PP roda ini mudah difahami oleh pelajar dan merangsang pemikiran sistematik mereka. Kenyataan ini sesuai dengan pelaksanaan kajian ini di mana pelajar perlu menjana idea dalam kumpulan melalui kaedah sumbang saran. Sebarang idea yang difikirkan logik dan bersesuaian dimasukkan dalam kitaran masing-masing. Malah, penggunaan PP roda ini memudahkan pelajar kerana konsep kitaran dalam roda membantu dalam pengumpulan data yang pantas.

Bagi menggabungkan pendekatan isu sosiosaintifik dengan peta pemikiran roda, pengkaji menggunakan kaedah pengintegrasian secara menyeluruh (Swartz \& Parks, 1994). Dalam kaedah ini, kemahiran pemikiran sains keusahawanan yang akan diajar dikenal pasti terlebih dahulu dan diajar bersama isi kandungan pelajaran secara serentak. Pengintegrasian menyeluruh diajar dalam lima langkah pengajaran iaitu (i) pengenalan, (ii) berfikir secara aktif, (iii) berfikir tentang pemikiran, (iv) latihan pengukuhan, dan (v) aplikasi pemikiran. Dalam hal ini, kedua-dua komponen (kandungan pelajaran dan kemahiran pemikiran sains keusahawanan) dilaksanakan secara saling berkait dalam setiap langkah pelaksanaannya.

Dalam pembinaan aktiviti unit dalam modul, pengkaji bersandar kepada Model Pembelajaran Pemikiran Sains Keusahawanan yang terbahagi kepada lima langkah iaitu i) membuat pemerhatian secara terancang dan bertujuan [Pemerhatian], ii) menghasilkan idea dengan mencari keunikan atau kelebihan [Idea Baharu], iii) memilih beberapa idea yang boleh diubah suai atau ditambah baik serta menilai idea-idea tersebut [Inovasi], iv) mengukuhkan dan menambah baik idea secara berfokus 
[Kreativiti], dan v) memastikan idea atau produk yang dihasilkan bermanfaat kepada masyarakat [Nilai].

Konklusinya, dalam reka bentuk dan pembangunan modul pengajaran dan pembelajaran PISPP, penyelidik mengadaptasikan Model ADDIE (Branch, 2010) yang terdiri daripada lima fasa iaitu analisis, reka bentuk, pembangunan, pelaksanaan dan penilaian. Model ADDIE dipilih pengkaji kerana Model ADDIE memfokuskan kepada aktiviti pembelajaran yang berpusatkan pelajar, reka bentuk pengajaran yang berorientasikan matlamat serta membolehkan pelajar menunjukkan tindakan yang bermakna dan menyelesaikan masalah secara praktikal.

Kerangka teoretikal dalam reka bentuk dan pembangunan modul pengajaran dan pembelajaran PISPP ditunjukkan dalam Rajah 1.

\section{Objektif dan Persoalan Kajian}

Kajian ini dijalankan untuk mereka bentuk dan membangunkan modul pengajaran dan pembelajaran yang mengintegrasikan pendekatan isu sosiosaintifik dan peta pemikiran roda untuk meningkatkan pemikiran sains keusahawanan dalam Pendidikan STEM bagi pelajar tahun lima. Terdapat tiga persoalan kajian yang memandu kajian ini iaitu:-

i. Adakah Modul PISPP yang dibangunkan sah, boleh dipercayai dan sesuai untuk pelajar tahun lima?

ii. Adakah terdapat perbezaan yang signifikan dalam kalangan pelajar tahun lima bagi kumpulan yang menerima modul PISPP dan kumpulan kawalan dalam i) min skor praujian? ii) min skor pascaujian dalam pemikiran sains keusahawanan?

iii. Apakah pengalaman yang dialami oleh pelajar tahun lima dalam menggunakan Modul PISPP dalam Pendidikan STEM?

\section{Metod Kajian}

\section{Reka bentuk Kajian}

Kajian ini mengaplikasikan reka bentuk deskriptif dan kuasi-eksperimental. Kajian deskriptif melibatkan penilaian dari aspek kesahan, kebolehpercayaan dan kesesuaian modul pengajaran dan pembelajaran PISPP. Manakala, reka bentuk kuasi-eksperimental pula diaplikasikan bagi menentukan kesan modul STEM PISPP terhadap pemikiran sains keusahawanan pelajar tahun lima. Kajian ini telah dijalankan selama 12 minggu bermula Oktober hingga Disember 2020.

\section{Sampel Kajian}

Kajian deskriptif melibatkan 30 orang pelajar tahun lima dan lima orang pakar penilai. Dalam mengukur ketekalan sesuatu instrumen yang baru dibangunkan, jumlah 30 orang responden adalah memadai (Chua, 2011). Dalam kajian kuasi eksperimental pula, seramai 60 orang pelajar tahun lima yang dilibatkan. Mereka dipilih secara rawak daripada dua buah sekolah bandar di Tawau, Sabah. Pelajar-pelajar ini dibahagikan kepada dua kumpulan iaitu kumpulan PISPP $(n=30)$ dan kumpulan kawalan $(n=30)$. Mereka terdiri daripada $29(48 \%)$ lelaki dan $31(52 \%)$ perempuan. Sejumlah $60 \%$ daripada ibu bapa pelajar-pelajar ini bekerja dalam sektor kerajaan manakala $40 \%$ lagi bekerja dalam sektor swasta dan perniagaan.

\section{Pertimbangan Etika}

Pada peringkat awal kajian, pengkaji mendapatkan kebenaran daripada guru besar, guru dan pelajarpelajar yang terlibat sebagai responden. Para responden diberi surat persetujuan untuk memohon kebenaran ibu bapa mereka untuk terlibat dalam penyelidikan. Surat persetujuan memperincikan 
penglibatan pelajar dalam penyelidikan dan persetujuan ibu bapa yang menunjukkan kefahaman mereka mengenai tujuan penyelidikan. Semua responden dijelaskan tentang kerahsiaan maklum balas mereka dan mereka boleh menarik diri daripada kajian tanpa dikenakan sebarang denda.

\section{Kajian Deskriptif}

\section{Fasa Analisis}

Tujuan utama pembangunan modul PISPP ini adalah untuk memupuk dan meningkatkan pemikiran sains keusahawanan pelajar tahun lima dalam pendidikan STEM yang diajar dalam mata pelajaran Sains. Bagi mencapai objektif pengajaran ini, para pengkaji melakukan analisis terhadap keperluan serta pelajar dan konteks. Semasa peringkat analisis keperluan, pengkaji telah menemu bual lima orang guru Sains tahun lima di Tawau, Sabah. Temu bual ini dijalankan pada 5 hingga 7 September 2020 bertempat di bilik guru sekolah rendah yang terlibat bagi mendapatkan gambaran bagaimana meningkatkan pemikiran sains keusahawanan melalui proses pengajaran dan pembelajaran. Kesemua guru memberi maklum balas bahawa mereka kurang pendedahan tentang konsep pemikiran sains keusahawanan dan proses pengajarannya kerana tidak ada panduan atau modul pengajaran dan pembelajaran yang boleh dirujuk berkaitan penerapan pemikiran sains keusahawanan di sekolah rendah. Melalui temu bual yang dijalankan, pengkaji juga mendapati bahawa guru-guru tidak pernah menerima kursus atau latihan berkaitan pemikiran sains keusahawanan ini.

Dalam analisis pelajar dan konteks, kriteria yang digunakan diadaptasi daripada idea Carlton et al. (2000) yang memfokuskan kepada unit yang tahap pencapaian pelajar agak rendah, pengetahuan lepas pelajar tentang tema Sains Fizikal serta Teknologi dan Kehidupan Lestari, kemahiran melakar, kemahiran mencipta dan tarikan rakan sekumpulan. Seramai 30 orang responden dipilih bagi mendapatkan maklum balas tentang analisis ini. Analisis menunjukkan pelajar-pelajar sependapat dalam semua aspek kecuali dalam aspek pengetahuan lepas pelajar tentang tema Sains Fizikal serta Teknologi dan Kehidupan Lestari yang agak lemah. Lantaran itu, pengajaran akan disesuaikan dengan tahap dan keperluan pelajar tahun lima sebaik mungkin.

\section{Reka Bentuk dan Pembangunan Modul PISPP}

Modul PISPP dibangunkan dengan mengadaptasikan pendekatan isu sosiosaintifik iaitu pembelajaran yang memperkenalkan isu sosial kepada pelajar, membantu mereka untuk mengkaji komponen sosial dan saintifik dalam isu tersebut, serta mendorong pelajar untuk mendapatkan penyelesaian isu bersandarkan nilai-nilai kemasyarakatan. Dalam membantu pelajar-pelajar menyelesaikan isu-isu sosiosaintifik yang diutarakan, peta pemikiran roda digunakan sebagai alat berfikir. Kedua-dua model ini diintegrasikan melalui model pengintegrasian pemikiran Swartz dan Parks (1994).

Modul ini terdiri daripada enam unit aktiviti STEM yang mencakupi tema Sains Fizikal serta Teknologi dan Kehidupan Lestari seperti yang terdapat dalam kandungan Dokumen Standard Kurikulum dan Pentaksiran Sains Tahun Lima semakan terkini (Bahagian Pembangunan Kurikulum, 2019). Setiap aktiviti diperuntukkan masa selama 180 minit. Namun demikian, cadangan masa pelaksanaan aktiviti ini boleh disesuaikan mengikut masa PdP di sekolah di mana modul ini boleh dilaksanakan di luar waktu PdP.

Modul PISPP direka bagi memupuk pemikiran sains keusahawanan pelajar-pelajar terhadap STEM melalui lima langkah iaitu (i) pemerhatian (membuat pemerhatian secara terancang dan bertujuan), (ii) idea baharu (menghasilkan idea dengan mencari keunikan atau kelebihan), (iii) inovasi (memilih beberapa idea yang boleh diubah suai atau ditambah baik dan menilai idea-idea tersebut), (iv) kreativiti (mengukuhkan dan menambah baik idea secara berfokus) dan (v) nilai (memastikan idea atau produk yang dihasilkan bermanfaat kepada masyarakat).

Dalam langkah pemerhatian, pelajar diminta membuat pemerhatian secara terancang dan bertujuan. Pelajar akan diberikan gambar rangsangan yang memaparkan rekaan produk zaman sekarang. 
Kemudian, pelajar diminta membuat pemerhatian untuk mendapatkan maklumat mengenai bahan binaan, reka bentuk dan ciri-ciri produk tersebut.

Seterusnya merupakan langkah idea baharu di mana pelajar perlu menghasilkan idea dengan mencari keunikan atau kelebihan. Dalam langkah ini, pelajar akan menghasilkan idea dengan mencari keunikan atau kelebihan pada produk yang diperhatikan dalam bahan binaan, reka bentuk dan ciri-ciri produk tersebut.

Langkah inovasi merujuk kepada aktiviti pelajar untuk memilih beberapa idea yang boleh diubah suai atau ditambah baik serta menilai idea-idea tersebut. Pemilihan idea-idea yang boleh ditambah baik ini akan membantu dalam menghasilkan rekaan produk pada masa hadapan. Pelajar kemudiannya perlu menilai idea-idea tersebut dengan menyatakan sebab-sebab mereka memilih idea tersebut.

Langkah kreativiti pula adalah aktiviti mengukuhkan dan menambah baik idea secara berfokus berdasarkan idea-idea yang dipilih dalam langkah sebelumnya. Pelajar akan menambah baik idea mereka dengan membuat lakaran rekaan, melabel dan membina model rekaan produk. Pelajar kemudiannya diminta menyatakan nama produk, harga yang ditawarkan dan kumpulan sasaran pembeli bagi produk tersebut.

Akhir sekali merupakan langkah nilai yang merujuk kepada aktiviti memastikan idea atau produk yang dihasilkan bermanfaat kepada masyarakat. Dalam langkah ini, pelajar akan menyatakan nilai-nilai produk yang mendatangkan manfaat atau kebaikan kepada masyarakat. Pelajar boleh menyatakan manfaat dari aspek penjimatan kos, fungsi produk serta nilai dan etika dalam penciptaan produk. Hal ini bagi memupuk nilai seperti cintakan alam sekitar dan amalan penggunaan bahan yang lestari dalam penghasilan produk untuk masyarakat. Pelajar seterusnya akan mempersembahkan produk rekaan di hadapan kelas dan membentangkan manfaat-manfaat produk mereka.

Kesemua langkah ini dilakukan secara berperingkat di dalam kitaran Peta Pemikiran Roda. Kelimalima langkah ini melibatkan aktiviti pelajar yang berbeza dalam setiap langkah. Bagi mendapatkan kesan yang maksimum, aktiviti dalam modul ini dilaksanakan dalam kumpulan bagi memastikan mereka saling bertukar idea dan mencari penyelesaian yang kreatif dan inovatif. Dalam pelaksanaan model ini juga, arahan dan bimbingan guru tetap diperlukan. Jadual 1 menunjukkan kaedah pengintegrasian Model Pendekatan Isu Sosiosaintifik dan Peta Pemikiran Roda dalam meningkatkan konstruk dalam Model Pembelajaran Pemikiran Sains Keusahawanan.

Jadual 1: Pengintegrasian PIS dan PP dalam Model Pembelajaran Pemikiran Sains Keusahawanan

\begin{tabular}{|c|c|c|}
\hline $\begin{array}{l}\text { Pendekatan Isu } \\
\text { Sosiosaintifik } \\
\text { (PIS) } \\
\end{array}$ & $\begin{array}{l}\text { Peta Pemikiran Roda } \\
\text { (PP) }\end{array}$ & $\begin{array}{l}\text { Pengintegrasian PIS dan } \\
\text { PP dengan Model Pembelajaran } \\
\text { Pemikiran Sains Keusahawanan } \\
\end{array}$ \\
\hline $\begin{array}{l}\text { Fasa } 1 \\
\text { Murid menemui atau } \\
\text { "diperkenalkan" dengan } \\
\text { sesuatu isu }\end{array}$ & $\begin{array}{l}\text { Kitaran Pertama - } \\
\text { Pemerhatian } \\
\text { Membuat pemerhatian secara } \\
\text { terancang dan bertujuan }\end{array}$ & $\begin{array}{l}\text { Pengenalan } \\
\text { Guru memperkenalkan isu sosiosaintifik } \\
\text { kepada murid dan meminta murid } \\
\text { membuat pemerhatian terhadap objek } \\
\text { dalam kitaran pertama PP roda }\end{array}$ \\
\hline \multirow[t]{2}{*}{$\begin{array}{l}\text { Fasa } 2 \\
\text { Murid mengkaji } \\
\text { komponen sosial dan } \\
\text { saintifik berhubung isu } \\
\text { dalam fasa pertama. }\end{array}$} & $\begin{array}{l}\text { Kitaran Kedua - Idea Baharu } \\
\text { Menghasilkan idea dengan } \\
\text { mencari keunikan atau } \\
\text { kelebihan pada produk yang } \\
\text { diperhatikan dalam bahan } \\
\text { binaan, reka bentuk dan ciri- } \\
\text { ciri produk tersebut. }\end{array}$ & $\begin{array}{l}\text { Berfikir secara aktif } \\
\text { Isu sosiosaintifik dan bahan rangsangan } \\
\text { digunakan sebagai panduan kepada } \\
\text { murid untuk menghasilkan idea dengan } \\
\text { mencari keunikan atau kelebihan } \\
\text { melalui kitaran kedua PP roda }\end{array}$ \\
\hline & $\begin{array}{l}\text { Kitaran Ketiga - Inovasi } \\
\text { Memilih beberapa idea yang } \\
\text { boleh diubah suai atau } \\
\text { ditambah baik dan menilai }\end{array}$ & $\begin{array}{l}\text { Berfikir tentang pemikiran } \\
\text { Murid dirangsang untuk memilih } \\
\text { beberapa idea yang boleh diubah suai } \\
\text { atau ditambah baik dan menilai idea- }\end{array}$ \\
\hline
\end{tabular}



DOI: https://doi.org/10.47405/mjssh.v7i1.1248

\begin{tabular}{|c|c|c|}
\hline & idea-idea tersebut & $\begin{array}{l}\text { idea tersebut melalui kitaran ketiga PP } \\
\text { roda bagi menyelesaikan isu yang } \\
\text { dikemukakan }\end{array}$ \\
\hline \multirow{3}{*}{$\begin{array}{l}\text { Fasa } 3 \\
\text { Murid berusaha } \\
\text { mendapatkan } \\
\text { penyelesaian isu } \\
\text { bersandarkan } \\
\text { nilai-nilai } \\
\text { kemasyarakatan. }\end{array}$} & Kitaran Keempat - Kreativiti & Latihan Pengukuhan \\
\hline & $\begin{array}{l}\text { Mengukuhkan dan } \\
\text { menambah baik idea secara } \\
\text { berfokus }\end{array}$ & $\begin{array}{l}\text { Murid mengukuhkan dan menambah } \\
\text { baik idea yang dipilih secara berfokus } \\
\text { dalam kitaran keempat PP roda dan } \\
\text { melakar idea bagi produk yang akan } \\
\text { dihasilkan }\end{array}$ \\
\hline & $\begin{array}{l}\text { Kitaran Kelima - Nilai } \\
\text { Memastikan idea atau produk } \\
\text { yang dihasilkan bermanfaat } \\
\text { untuk masyarakat }\end{array}$ & $\begin{array}{l}\text { Aplikasi pemikiran } \\
\text { Murid menyatakan dan memastikan } \\
\text { ciri-ciri produk yang dihasilkan } \\
\text { bermanfaat untuk masyarakat dan dapat } \\
\text { menyelesaikan isu yang diutarakan } \\
\text { dalam kitaran kelima PP roda }\end{array}$ \\
\hline
\end{tabular}

\section{Fasa Penilaian}

Taherdoost (2016) menjelaskan bahawa kesahan kandungan perlu ditentukan sebelum sesuatu modul digunakan. Fasa kedua penilaian pula dijalankan bagi menilai kebolehpercayaan modul, kebolehlaksanaan dan penerimaan modul oleh responden. Fasa ini dijalankan selepas Modul PISPP dijalankan ke atas responden. Seperti yang ditekankan oleh Cohen dan Swedlik (2018), modul yang baik biasanya mempunyai kesahan dan kebolehpercayaan yang tinggi.

Seramai lima panel pakar terlibat dalam memastikan kesahan kandungan modul. Pakar-pakar tersebut adalah pensyarah universiti, pensyarah institut pendidikan guru serta guru-guru sains sekolah rendah. Pakar pemikiran sains keusahawanan dan STEM merupakan seorang profesor di universiti awam dan pensyarah di institut pendidikan guru. Dua orang pakar merupakan guru yang berpengalaman luas dalam pendidikan sains sekolah rendah.

Bagi mengukur kesahan kandungan modul, borang penilaian modul diberikan kepada para pakar bagi membolehkan mereka memberikan maklum balas yang jelas mengenai kandungan pedagogi (pendekatan isu sosiosaintifik, peta pemikiran roda dan STEM), gambaran keseluruhan aktiviti, kesesuaian setiap rancangan pelajaran, standard pembelajaran, keseluruhan perjalanan unit aktiviti, pengintegrasian lima langkah pemikiran sains keusahawanan, dan komen bertulis untuk menambah baik modul. Modul PISPP dihasilkan dalam Bahasa Melayu bagi memastikan pemahaman kandungan modul dalam kalangan guru sekolah rendah.

Soal selidik juga diberikan kepada responden untuk mendapatkan persepsi pelajar terhadap kesesuaian aktiviti dalam Modul PISPP. Soal selidik menggunakan skala Likert 5 mata dengan nilai 1 (sangat tidak setuju) hingga 5 (sangat setuju). Sebanyak 11 soalan yang diadaptasi daripada Rahman (2020) memerlukan pelajar untuk memberikan maklum balas dari aspek perasaan, manfaat dalam pelaksanaan lima langkah pemikiran sains keusahawanan, penggunaan pendekatan isu sosiosaintifik dan peta pemikiran roda.

Bagi memastikan kebolehpercayaan Modul PISPP, satu lagi set soal selidik yang diadaptasi daripada Ambo (2019) juga diberikan kepada responden. Noah dan Ahmad (2005) menzahirkan bahawa soal selidik berdasarkan aktiviti menunjukkan indeks kebolehpercayaan yang lebih tinggi berbanding objektif dalam modul. Terdapat enam aktiviti dalam modul PISPP dan setiap aktiviti dalam modul dinilai oleh lima item menggunakan skala Likert dengan nilai 1 (sangat tidak setuju) hingga 5 (sangat setuju). Item-item yang disoal adakah setiap aktiviti yang dijalankan dapat membantu responden untuk memupuk lima konstruk pemikiran sains keusahawanan sesuai dengan hasil pembelajaran modul. Kesemua 30 item diutarakan dalam laras bahasa yang sesuai bagi pelajar sekolah rendah. Kedua-dua borang soal selidik ini diberikan kepada 30 orang pelajar tahun lima dalam kumpulan PISPP setelah intervensi menggunakan modul dijalankan. 
Penutup fasa penilaian dilakukan dengan menjalankan sesi temu bual secara kumpulan berfokus dijalankan bagi mendapatkan maklum balas pelajar tentang pelaksanaan modul PISPP. Mereka diminta untuk menzahirkan perasaan dan pengalaman setelah mengikut modul PISPP serta bagaimana modul tersebut memberi implikasi kepada mereka dari segi pemikiran sains keusahawanan.

\section{Kajian Kuasi Eksperimental}

Fasa pelaksanaan kajian eksperimental melibatkan pelaksanaan modul pengajaran dan pembelajaran PISPP serta menilai keberkesanannya dalam sesi pengajaran dan pembelajaran di dalam bilik darjah. Selaras dengan itu, reka bentuk kuasi eksperimen Ujian Pra-Pasca Kumpulan Kawalan Tak-Setara digunakan. Sebanyak 60 orang pelajar tahun lima dipilih secara rawak dari dua buah sekolah rendah di daerah Tawau dan dibahagikan kepada dua kumpulan; kumpulan rawatan (PISPP, n=30), dan kumpulan kawalan (KK, $\mathrm{n}=30$ ). Responden dalam kumpulan rawatan menerima modul PISPP yang mencakupi 6 unit pembelajaran selama 12 minggu sepanjang Oktober hingga Disember 2020. Setiap unit memerlukan 180 minit masa pelaksanaan dengan tiga misi yang perlu diselesaikan iaitu; Misi 1: Perbincangan Isu Sosiosaintifik, Misi 2: Perbincangan Model Rekaan dan Misi 3: Pembentangan Model Rekaan. Ketiga-tiga misi ini boleh dijalankan secara tiga peringkat mengikut kesesuaian masa pengajaran dan pembelajaran di sekolah. Responden dalam kumpulan kawalan pula didedahkan dengan kaedah penghasilan model rekaan yang konvensional tanpa menggunakan pendekatan isu sosiosaintifik dan peta pemikiran roda.

Bagi menilai keberkesanan modul, instrumen Ujian Pemikiran Sains Keusahawanan (UPSK) (Ahmad \& Siew, 2021) yang dibangunkan oleh pengkaji sendiri digunakan. Instrumen ini telah terbukti sah, boleh dipercayai dan sesuai digunakan bagi menilai pemikiran sains keusahawanan pelajar tahun lima. UPSK yang mencakupi 10 item memerlukan pelajar untuk menjawab soalan dalam pernyataan dan lakaran idea. Item soalan dibangunkan berdasarkan lima konstruk dalam Pemikiran Sains Keusahawanan (Buang et al., 2009) dengan merujuk kepada kandungan DSKP Sains Tahun Lima di bawah tema Sains Fizikal serta Teknologi dan Kehidupan Lestari (Bahagian Pembangunan Kurikulum, 2014:61-79). Soalan utama yang diutarakan meminta pelajar untuk menghasilkan suatu rekaan telefon bimbit untuk kegunaan masyarakat pada masa hadapan. Konteks penggunaan telefon bimbit dipilih kerana ia terkandung dalam DSKP di bawah tema Sains Fizikal. Pelajar kemudiannya diberikan gambar rangsangan dan diberi sepuluh item soalan yang disusun mengikut kelompok konstruk bagi membolehkan pelajar mengorganisasi jawapan dan seterusnya mengarah kepada dapatan yang diharapkan. Penskoran UPSK dilakukan berdasarkan skor pemarkahan Ho et al. (2013). Setiap item yang disediakan dalam ujian ini membawa skor minimum 0 dan skor maksimum tiga.

\section{Analisis Data}

Data kajian deskriptif diperolehi dengan membuat kiraan peratus, min dan sisihan piawai. Manakala data kajian inferensi diperolehi melalui analisis IBM SPSS (versi 26). Bagi analisis ini, aras kesignifikanan ditetapkan pada nilai .05. Bagi analisis soalan temu bual kumpulan berfokus, pengkaji menggunakan analisis tematik (Braun \& Clarke, 2006) bagi mendapatkan tema-tema daripada temu bual mengenai pengalaman yang dialami oleh 30 orang pelajar tahun lima setelah menggunakan Modul PISPP dalam Pendidikan STEM. Pengkaji mengupas data-data temu bual secara terperinci dan mendapatkan keterkaitan pola dalam pengalaman responden dan menjelaskan pengalaman responden melalui pemerhatian pengkaji (Fereday \& Muir-Cochrane, 2006).

\section{Hasil Kajian}

\section{Kesahan Kandungan}

Seramai lima orang pakar penilai terlibat dalam penentuan kesahan kandungan Modul PISPP. Sesuai dengan saranan pakar, beberapa pindaan telah dibuat terhadap kandungan dan aktiviti dalam Modul PISPP; 1) aktiviti penghasilan model rekaan mengikut konstruk dimurnikan bagi memenuhi konsep Pemikiran Sains Keusahawanan; 2) format penulisan RPH diringkaskan bagi pemahaman yang jelas; 
DOI: https://doi.org/10.47405/mjssh.v7i1.1248

3) penulisan hasil pembelajaran dispesifikkan mengikut standard kandungan setiap unit; 4) susunan aktiviti di dalam modul diubah mengikut susunan standard kandungan dalam DSKP; dan 5) penerangan ringkas bagi setiap konsep penting ditambah bagi meningkatkan kefahaman pembaca modul. Secara keseluruhan, para pakar penilai berpendapat bahawa modul PISPP adalah modul yang sesuai untuk memupuk pemikiran sains keusahawanan dalam kalangan pelajar tahun lima.

\section{Kebolehpercayaan}

Kebolehpercayaan modul ditentukan berdasarkan pekali konsistensi dalaman Cronbach Alfa untuk menentukan tahap pengukuran aktiviti dengan modul dan konstruk yang sama untuk mendapatkan hasil yang konsisten (Cohen et al., 2018). Kebolehpercayaan modul dijalankan setelah responden dapat menguasai objektif dan boleh mengikuti langkah-langkah untuk setiap aktiviti dalam modul ini pada tahap yang baik. Hair et al. (2006) mencadangkan bahawa pekali alfa $\geq .7$ adalah boleh diterima manakala Sekaran dan Bougie (2010) pula menyatakan pekali alfa $\geq .8$ biasanya mempunyai kebolehpercayaan yang tinggi. Jadual 1 menunjukkan nilai Alfa Cronbach bagi aktiviti pembelajaran dalam Modul PISPP yang diperolehi daripada soal selidik 10 item ke atas 30 orang responden. Nilai keseluruhan Alfa Cronbach modul PISPP ialah .82 dengan nilai antara .74 hingga .89 bagi setiap unit dalam modul. Ini menunjukkan kebolehpercayaan bagi setiap unit aktiviti dalam modul boleh diterima dan keseluruhan modul PISPP yang dibangunkan adalah tinggi.

Jadual 2: Nilai Alfa Cronbach bagi aktiviti pembelajaran dalam Modul PISPP

\begin{tabular}{lll}
\hline Unit & Unit dalam modul & Alfa Cronbach \\
\hline 1 & Kereta Alaf Baharu & .89 \\
2 & Lampu Jimat Tenaga & .77 \\
3 & Kaca Mata Solarku & .79 \\
4 & Televisyen Lima Bintang & .84 \\
5 & Rumah Lestariku & .86 \\
6 & Bekas Makanan Mesra Alam & .74 \\
\hline & Keseluruhan & .82 \\
\hline
\end{tabular}

\section{Persepsi Pelajar Terhadap Modul}

Jadual 3 memaparkan persepsi pelajar terhadap modul yang diperolehi melalui soal selidik ke atas responden. Nilai min keseluruhan 4.53 menunjukkan bahawa modul PISPP mempunyai nilai penerimaan atau kebolehlaksanaan yang tinggi. Seramai 30\% responden bersetuju dan $63 \%$ sangat bersetuju dengan kebolehlaksanaan modul PISPP. Kriteria yang mempunyai tahap min minimum 3.50 menunjukkan aspek kebolehlaksanaan modul boleh diterima (Junus et al., 2021). Namun, jika tahap min adalah di bawah 3.50, perubahan perlu dibuat kerana aspek kebolehlaksanaan modul dianggap tidak memuaskan. Dapatan kajian pada tahap min antara 4.06 hingga 4.86 menunjukkan pelajarpelajar tahun lima bersetuju bahawa Modul PISPP boleh digunakan untuk memupuk pemikiran sains keusahawanan dalam kalangan pelajar tahun lima.

Jadual 3: Peratus dan Min Bagi Persepsi Pelajar Terhadap Modul

\begin{tabular}{llllllll}
\hline & & \multicolumn{3}{l}{ Peratus dan min mengikut skala } & & \\
\cline { 2 - 8 } Bil & $\begin{array}{l}\text { Kriteria Kebolehlaksanaan } \\
\text { Pedagogi }\end{array}$ & $\begin{array}{l}\text { Sangat } \\
\text { tidak } \\
\text { setuju }\end{array}$ & $\begin{array}{l}\text { Tidak } \\
\text { setuju }\end{array}$ & $\begin{array}{l}\mathbf{3} \\
\text { Neutral }\end{array}$ & $\begin{array}{l}\mathbf{4} \\
\text { Setuju }\end{array}$ & $\begin{array}{l}\text { S } \\
\text { Sangat } \\
\text { setuju }\end{array}$ & Min \\
\hline 1 & $\begin{array}{l}\text { Aktiviti pembelajaran sains } \\
\text { menggunakan Modul PISPP }\end{array}$ & 0 & 0 & 1 & 5 & 24 & 4.76 \\
$\begin{array}{l}\text { merangsang minda saya untuk mencari } \\
\text { penyelesaian bagi isu sosial yang } \\
\text { dikemukakan. }\end{array}$ & $(0)$ & $(0)$ & $(3)$ & $(17)$ & $(80)$ & \\
\hline
\end{tabular}


2 Aktiviti pembelajaran sains menggunakan Modul PISPP merangsang minda saya untuk

0 menghasilkan banyak idea baharu.

3 Aktiviti pembelajaran sains menggunakan Modul PISPP merangsang minda saya untuk menghasilkan idea yang boleh diaplikasikan mengikut kehendak semasa.

$4 \quad$ Aktiviti pembelajaran sains menggunakan Modul PISPP merangsang minda saya untuk mengembangkan idea asal kepada idea baharu yang lebih menarik

5 Aktiviti pembelajaran sains menggunakan Modul PISPP merangsang minda saya untuk menghasilkan model rekaan yang dapat memanfaatkan masyarakat.

6 Aktiviti pembelajaran sains menggunakan Modul PISPP meningkatkan lagi kualiti model rekaan yang dihasilkan.

$7 \quad$ Aktiviti pembelajaran sains menggunakan Modul PISPP meningkatkan pengetahuan sains dalam diri saya.

8 Aktiviti pembelajaran sains menggunakan Modul PISPP meningkatkan orientasi keusahawanan dalam diri saya.

$9 \quad$ Saya berasa seronok sepanjang mengikuti pembelajaran sains menggunakan Modul PISPP.

$\begin{array}{lllll}0 & 0 & 1 & 14 & 15\end{array}$

$\begin{array}{llll}(0) & (0) \quad(3) \quad(50)\end{array}$

$\begin{array}{lllll}0 & 1 & 2 & 7 & 20 \\ (0) & (3) & (7) & (23) & (67)\end{array}$

$\begin{array}{lllll}0 & 1 & 2 & 10 & 17 \\ (0) & (3) & (7) & (33) & (57)\end{array}$

Sifat ingin tahu saya dalam Pendidikan STEM semakin bertambah setelah mengikuti pembelajaran sains menggunakan Modul PISPP.

$\begin{array}{lllll}0 & 2 & 4 & 14 & 10\end{array}$

(0) (7) (13) (47) (33)

4.06

0

(0)

0

0

$4 \quad 26$

(13) (87)

0

2

\section{2}

13

0

1

2

8

(0)

(3)

(7)

(27)

0

(0)

1

2

$6 \quad 21$

(20) (70)

11 Saya semakin berminat untuk mengikuti aktiviti pembelajaran menggunakan Modul PISPP pada masa akan datang.

Keseluruhan

$\begin{array}{ll}0 & 0 \\ (0) & (0)\end{array}$

\section{0}

5

\begin{tabular}{llllll}
0 & 8 & 16 & 100 & 206 & 4.53 \\
$(0)$ & $(2)$ & $(5)$ & $(30)$ & $(63)$ & \\
\hline
\end{tabular}

\section{Keberkesanan Modul PISPP}

\section{Ujian-T Sampel Bersandaran}

Ujian-t sampel bersandaran dijalankan untuk menentukan adakah terdapat perbezaan yang signifikan di antara min skor praujian dan pascaujian bagi kumpulan PISPP dari aspek lima konstruk pemikiran sains keusahawanan. Dapatan kajian dalam Jadual 4 menunjukkan bahawa min skor pascaujian berbeza secara signifikan dengan min skor praujian dari aspek konstruk Pemerhatian, Idea Baharu, Inovasi, Kreativiti dan Nilai dengan nilai masing-masing $(t(29)=-20.707, p<.05 ; t(29)=-23.404, p<$ 
DOI: https://doi.org/10.47405/mjssh.v7i1.1248

$.05 ; t(29)=-28.580, p<.05 ; t(29)=-25.284, p<.05 ; t(29)=-24.814, p<.05)$. Dapatan menunjukkan bahawa kumpulan PISPP mempunyai prestasi yang lebih tinggi dalam pascaujian berbanding praujian dalam kelima-lima konstruk pemikiran sains keusahawanan.

Dapatan analisis Ujian-t sampel bersandaran bagi kumpulan kawalan (KK) (Jadual 4) juga turut menunjukkan perbezaan yang lebih tinggi secara signifikan bagi pascaujian berbanding praujian dari aspek konstruk Pemerhatian, Idea Baharu, Inovasi, Kreativiti dan Nilai dengan nilai masing-masing $(t(29)=-7.990, p<.05 ; t(29)=-7.999, p<.05 ; t(29)=-5.530, p<.05 ; t(29)=-6.998, p<.05 ; t(29)=$ $-7.940, p<.05)$. Dapatan ini membuktikan bahawa KK juga menunjukkan prestasi yang lebih tinggi dalam pascaujian berbanding praujian dalam kelima-lima konstruk pemikiran sains keusahawanan.

Jadual 4: Keputusan Analisis Ujian-t Sampel Bersandaran

\begin{tabular}{|c|c|c|c|c|c|c|c|}
\hline \multirow{2}{*}{ Konstruk } & \multirow{2}{*}{ Kumpulan } & Praujian & Pascaujian & Perbezaan & $t$ & $d f$ & $p$ \\
\hline & & \multicolumn{6}{|c|}{ Min (Sisihan Piawai) } \\
\hline \multirow[t]{2}{*}{ Pemerhatian } & PISPP & $2.37(.669)$ & $4.93(.640)$ & $\begin{array}{l}-2.567 \\
(.679)\end{array}$ & -20.707 & 29 & $\mathrm{p}<.05$ \\
\hline & KK & $2.30(.596)$ & $3.57(.568)$ & $\begin{array}{l}-1.267 \\
(.868)\end{array}$ & -7.990 & 29 & $\mathrm{p}<.05$ \\
\hline \multirow[t]{2}{*}{ Idea Baharu } & PISPP & $2.23(.679)$ & $4.97(.615)$ & $\begin{array}{l}-2.733 \\
(.640)\end{array}$ & -23.404 & 29 & $\mathrm{p}<.05$ \\
\hline & KK & $2.27(.691)$ & $3.40(.894)$ & $\begin{array}{c}-1.133 \\
(.776)\end{array}$ & -7.999 & 29 & $\mathrm{p}<.05$ \\
\hline \multirow[t]{2}{*}{ Inovasi } & PISPP & $2.47(.819)$ & $5.07(.868)$ & $\begin{array}{l}-2.600 \\
(.498)\end{array}$ & -28.580 & 29 & $\mathrm{p}<.05$ \\
\hline & KK & $2.50(.731)$ & $3.33(.661)$ & $\begin{array}{l}-.833 \\
(.699)\end{array}$ & -6.530 & 29 & $\mathrm{p}<.05$ \\
\hline \multirow[t]{2}{*}{ Kreativiti } & PISPP & $2.57(.774)$ & $5.17(.699)$ & $\begin{array}{l}-2.600 \\
(.563)\end{array}$ & -25.284 & 29 & $\mathrm{p}<.05$ \\
\hline & KK & $2.60(.621)$ & $3.63(.765)$ & $\begin{array}{l}-1.033 \\
(.809)\end{array}$ & -6.998 & 29 & $\mathrm{p}<.05$ \\
\hline \multirow[t]{2}{*}{ Nilai } & PISPP & $2.40 .675)$ & $5.10(.712)$ & $\begin{array}{l}-2.700 \\
(.596)\end{array}$ & -24.814 & 29 & $\mathrm{p}<.05$ \\
\hline & KK & $2.40(.675)$ & $3.50(.682)$ & $\begin{array}{l}-1.100 \\
(.759) \\
\end{array}$ & -7.940 & 29 & $\mathrm{p}<.05$ \\
\hline
\end{tabular}

Nota: Aras kesignifikanan pada $\mathrm{p}=.05$

\section{Ujian-T Sampel Tak Bersandaran}

Ujian-t sampel tak bersandaran dijalankan untuk membandingkan min skor dalam praujian bagi kelima-lima konstruk di antara kumpulan PISPP dan KK. Keputusan analisis (Jadual 4) menunjukkan bahawa tidak terdapat perbezaan yang signifikan di antara min skor praujian antara kumpulan PISPP dan KK dalam konstruk Pemerhatian, Idea Baharu, Inovasi, Kreativiti dan Nilai dengan nilai masingmasing $(t(58)=.408, p>.05 ; t(58)=-.188, p>.05 ; t(58)=-.166, p>.05 ; t(58)=-.184, p>.05$; $t(58)=.00, p>.05)$.

Gay dan Airasian (2003) menyatakan bahawa jika tidak terdapat perbezaan signifikan bagi min skor di antara kedua-dua praujian, maka ujian-t terhadap min skor pascaujian boleh dilakukan. Oleh itu, ujian$\mathrm{t}$ sampel tak bersandaran dilakukan untuk membandingkan min skor kumpulan PISPP dan kawalan dalam kelima-lima konstruk pemikiran sains keusahawanan. Keputusan analisis menunjukkan bahawa responden dalam kumpulan PISPP mempunyai skor yang lebih tinggi secara signifikan berbanding kumpulan kawalan dari aspek konstruk Pemerhatian, Idea Baharu, Inovasi, Kreativiti dan Nilai dengan nilai masing-masing $(t(58)=8.748, p<.05 ; t(58)=7.906, p<.05 ; t(8)=8.700, p<.05 ; t(58)=8.106$, $p<.05 ; t(58)=8.887, p<.05)$. Keputusan ini membuktikan bahawa terdapat perbezaan yang signifikan dalam pascaujian bagi pelajar dalam kumpulan PISPP berbanding kumpulan kawalan dalam kelima-lima konstruk pemikiran sains keusahawanan. 
DOI: https://doi.org/10.47405/mjssh.v7i1.1248

Jadual 5: Keputusan Analisis Ujian-t Sampel Tak Bersandaran

\begin{tabular}{llllllll}
\hline Konstruk & Ujian & $\begin{array}{l}\text { Kumpulan } \\
\text { PISPP } \\
\text { Min (SP) }\end{array}$ & $\begin{array}{l}\text { Kumpulan } \\
\text { Kawalan } \\
\text { Min (SP) }\end{array}$ & $\begin{array}{l}\text { Perbezaan } \\
\text { Kumpulan }\end{array}$ & $\boldsymbol{t}$ & $\boldsymbol{d}$ f & $\boldsymbol{p}$ \\
\hline Pemerhatian & Pra & $2.37(.669)$ & $2.30(.596)$ & $.067(.164)$ & .408 & 58 & $\mathrm{p}>.05$ \\
& Pasca & $4.93(.640)$ & $3.57(.568)$ & $1.367(.156)$ & 8.748 & 58 & $\mathrm{p}<.05$ \\
Idea Baharu & Pra & $2.23(.679)$ & $2.27(.691)$ & $-.033(.177)$ & -.188 & 58 & $\mathrm{p}>.05$ \\
& Pasca & $4.97(.615)$ & $3.40(.894)$ & 1.567 & 7.906 & 58 & $\mathrm{p}<.05$ \\
Inovasi & & & $(.198)$ & & & \\
& Pra & $2.47(.819)$ & $2.50(.731)$ & $-.033(.200)$ & -.166 & 58 & $\mathrm{p}>.05$ \\
& Pasca & $5.07(.868)$ & $3.33(.661)$ & 1.733 & 8.700 & 58 & $\mathrm{p}<.05$ \\
Kreativiti & & & & $(.199)$ & & & \\
& Pra & $2.57(.774)$ & $2.60(.621)$ & $-0.33(.181)$ & -.184 & 58 & $\mathrm{p}>.05$ \\
& Pasca & $5.17(.699)$ & $3.63(.765)$ & 1.533 & 8.106 & 58 & $\mathrm{p}<.05$ \\
Nilai & & & & $(.189)$ & & & \\
& Pra & $2.40(.675)$ & $2.40(.675)$ & $0.00(.174)$ & 0.00 & 58 & $\mathrm{p}>.05$ \\
& Pasca & $5.10(.712)$ & $3.50(.682)$ & 1.600 & 8.887 & 58 & $\mathrm{p}<.05$ \\
& & & & $(.180)$ & & & \\
\hline
\end{tabular}

Nota: Aras kesignifikanan pada $p=.05$

\section{Temu Bual Kumpulan Berfokus}

Beberapa tema yang telah dikenal pasti hasil daripada pandangan responden dalam temu bual kumpulan berfokus terhadap pelaksanaan modul pengajaran dan pembelajaran PISPP. Dapatan adalah seperti berikut:

\section{Penyusunan idea dan perkembangan idea baharu}

Penggunaan Modul PISPP membantu pelajar menyusun idea dengan lebih teratur dan mengembangkan idea baharu mereka.

"Masa kami diminta menulis dalam roda, saya cakap dalam hati, kenapa nak buat roda? Kan kita boleh terus hasilkan produk? Tapi masa dah buat tu, dengan idea yang datang satu per satu, baru rasa pentingnya ada roda. Kalau takda roda, memang susahlah. Tak tahu macam mana nak susun idea..." (P2)

“... peta ini memberi peluang baharu kepada pelajar untuk membuka idea mereka. Sebab ada produk baharu yang perlu dihasilkan...” (P1)

“... sebelum kami hasilkan objek, saya rasa sangat gemuruh. Tapi gara-gara peta roda itu yang menolong saya, saya rasa senang untuk hasilkan. Peta roda itu ada kitaran yang berperingkat-peringkat. Jadi ini sangat membantu. Sampai sahaja kitaran keempat, saya rasa tugasan ini senang sebenarnya..." (P5)

“... idea dapat disusun dengan mudah. Kami dapat hasilkan ciptaan produk dengan lebih sistematik..." (P14)

“..sebarang maklumat yang terlintas dan idea yang kami fikirkan tidak akan tercicir..." (P15)

\section{Peningkatan ilmu STEM}

Pelajar turut menyatakan bahawa inovasi Modul PISPP ini meningkatkan lagi ilmu STEM mereka. 
“..saya sangat teruja untuk belajar STEM dengan adanya kaedah ini...” (P3)

“.. saya tidak sangka peta roda ni bantu saya kenal dan belajar apa itu STEM.." (P11)

"Pada awalnya, saya sendiri tertanya-tanya apa itu STEM. Lepas tulis dalam peta roda tu, baru saya faham. Sebab kami kena hasilkan produk guna ilmu sains, teknologi, kejuruteraan dan matematik.." (P13)

\section{Perasaan seronok dalam menghasilkan prototaip}

Pelajar menzahirkan rasa teruja dan seronok dalam menghasilkan prototaip.

“.. tadi, kami hasilkan kereta yang menggunakan air sebab penggunaan bahan api fosil sudah tidak sesuai untuk alam sekitar. Saya rasa ini sangat menyeronokkan sebab peta banyak bantu kami hasilkan kereta tu. Kami susun idea kami satu-satu sampai terhasil tu kereta.." (P10)

“...saya kagum dengan diri saya sendiri. Kami dalam kumpulan tidak sangka boleh hasilkan produk untuk masa hadapan. Saya betul-betul gembira...” (P12)

\section{Pemupukan sifat membantu masyarakat masa hadapan}

Penggunaan inovasi Modul PISPP ini ternyata membantu pelajar melahirkan rasa untuk menyelesaikan isu sejagat demi membantu masyarakat masa hadapan.

"Pada mulanya, kami diberikan isu untuk berbincang. Saya pun tidak tahu rupanya dunia kita sedang alami masalah yang macam cikgu tunjukkan. Jadi dalam roda, kami tulis isu yang kami bincangkan, lepas tu kami tulis idea-idea untuk hasilkan produk. Roda tu sangat membantu untuk bantu masyarakat masa hadapan..." (P7)

“. pada mulanya, saya takut projek ini tidak menjadi... Tapi apabila dibuat secara berkumpulan... dapat hasilkan produk yang kami mahukan untuk masyarakat masa hadapan" (P9)

\section{Peningkatan sifat ingin tahu}

Sifat ingin tahu pelajar juga dapat ditingkatkan melalui inovasi Modul PISPP ini.

“.. semasa nak hasilkan produk tu, kami saling menyoal dalam kumpulan. Sebab kami mahu tahu apa jadi kalau buat begini? Kenapa kita mesti buat begini? Kami mahu tahu hasilnya.." (P13)

“.. sebenarnya, kami takut apa yang kami rancang tak jadi. Tapi selepas tulis idea dalam peta tu, kami buat apa yang dirancang, akhirnya jadi juga. Yalah. Sebab bila kita sudah tulis idea, kita tidak sabar mahu tahu apa akan jadi lepas tu..” (P2)

\section{Pemupukan sifat bekerjasama dalam pasukan}

Nilai bekerjasama dan kesepakatan dalam pasukan dapat dipupuk melalui pelaksanaan inovasi Modul PISPP.

“... peta roda bantu saya untuk bekerjasama dengan kawan-kawan dalam menghasilkan projek kumpulan kami...” (P4) 
“...saya rasa semua kerja kami jadi mudah. Sebab roda tu kami hasilkan samasama, kami bincang sama-sama untuk mendapatkan idea. Akhirnya, kami berjaya hasilkan." (P6)

“.. saya rasa sangat gementar, sebab takut tersilap. Tapi lepas buat, saya rasa sangat gembira. Sebab semua kami buat sama-sama dengan kawan-kawan” (P8)

“.. pada mulanya, saya takut projek ini tidak menjadi. Tapi apabila dibuat secara berkumpulan, apa yang kami bincangkan bersama, dapat hasilkan produk yang kami mahukan untuk masyarakat masa hadapan" (P9)

\section{Perbincangan}

Kajian ini dijalankan untuk membangunkan modul PISPP yang lebih terarah ke arah memenuhi keperluan pelajar mendepani Revolusi Industri 4.0. Bagi memastikan kebolehlaksanaannya di sekolahsekolah, penilaian ke atas kesahan, kebolehpercayaan, kesesuaian dan kesannya telah dianalisis. Modul PISPP dibangunkan berdasarkan kerangka teoretikal yang jelas dan terperinci dengan menggabungkan Model Pembelajaran Pendekatan Isu Sosiosaintifik dan kaedah Peta Pemikiran Roda menggunakan Model Pengintegrasian Swartz dan Park (1994) untuk melihat kesan ke atas lima konstruk dalam Model Pembelajaran Pemikiran Sains Keusahawanan.

Secara keseluruhan, dapatan kajian telah membuktikan bahawa modul PISPP mempunyai kesahan kandungan yang baik dan boleh diterima dalam meningkatkan pemikiran sains keusahawanan pelajar tahun lima. Analisis mengenai kesahan kandungan modul membuktikan bahawa Modul PISPP diterima baik oleh kelima-lima pakar penilai dengan melakukan beberapa penambahbaikan terhadap beberapa aspek dalam modul. Analisis kebolehpercayaan modul menunjukkan bahawa modul PISPP berada dalam julat yang boleh diterima berdasarkan nilai alfa Cronbach. Kajian ini telah membuktikan bahawa pengintegrasian Model Pendekatan Isu Sosiosaintifik, kaedah peta Pemikiran Roda, Model Pengintegrasian Swartz dan Park (1994), model pemikiran sains keusahawanan dan model reka bentuk instruksional ADDIE membuktikan bahawa Modul PISPP adalah sah dan boleh dipercayai dalam pendidikan STEM.

Hasil ujian T sampel bersandaran menunjukkan bahawa pelajar tahun lima dalam kedua-dua kumpulan PISPP dan KK menunjukkan prestasi yang lebih baik dalam lima konstruk pemikiran sains keusahawanan dalam pascaujian berbanding praujian. Namun, pelajar tahun lima yang diajar dalam kumpulan PISPP mempunyai skor peningkatan yang jauh lebih besar berbanding dengan rakan sebaya mereka yang diajar dalam kumpulan pembelajaran KK. Hal ini bermakna, peluang untuk belajar dengan modul pengajaran dan pembelajaran PISPP memberi kesan mendalam terhadap pemikiran sains keusahawanan pelajar tahun lima. Bagi hasil ujian-T sampel tak bersandaran, dapatan menunjukkan bahawa penggunaan modul pengajaran dan pembelajaran PISPP dapat memupuk pemikiran sains keusahawanan secara berkesan.

Pendedahan kepada isu sosiosaintifik dalam modul PISPP membolehkan pelajar membuat hubung kait isu sosiosaintifik yang diutarakan dengan pengalaman mereka. Perbincangan isu-isu sosiosaintifik mendorong kepada permulaan dalam pemerhatian dan penyiasatan sesuatu fenomena atau situasi (Darmaji et al., 2019; Kohlhauf et al., 2011). Penghujahan isu sosiosaintifik yang dibuat bersama analisis data pemerhatian akan menggalakkan pelajar untuk melihat pola dan meramal situasi yang belum berlaku atau belum diperhatikan (Syukri et al., 2013). Hal ini membuktikan bahawa pendekatan isu sosiosaintifik membantu memberikan gambaran awal tentang konsep produk yang bakal dicipta.

Tambahan lagi, pendedahan isu sosiosaintifik melalui Modul PISPP membuka ruang kepada pelajar untuk meluaskan pelbagai sudut pengetahuan isu (Khishfe et al., 2017). Dalam isu sosiosaintifik yang diutarakan dalam setiap unit aktiviti, isu tersebut dilengkapi dengan contoh dan gambar yang menunjukkan situasi sosiosaintifik yang sedang berlaku. Pendekatan pengenalan isu sosiosaintifik juga membolehkan pelajar membuat pemerhatian berdasarkan situasi semasa yang berlaku seperti isu 
pencemaran yang kian kritikal. Maklumat dalam isu ini memberi input kepada pelajar untuk membuat ciptaan produk yang dapat menyelesaikan isu sosiosaintifik yang diutarakan.

Selain itu, peningkatan min skor pelajar yang mengikuti PISPP berbanding KK ini dapat dihuraikan melalui langkah isu sosiosaintifik yang begitu terperinci (Topçu et al., 2018). Dalam fasa pertama pendekatan isu sosiosaintifik yang menemukan pelajar dengan fokus isu, pelajar dibimbing untuk membuat pemerhatian awal tentang objek-objek yang dibincangkan dalam isu. Kemudiannya, dalam fasa kedua iaitu membuat hubungan dengan idea sains dan membuat hubungan dengan kepekaan masyarakat, pelajar meningkatkan kemahiran pemerhatian dengan bertanyakan soalan dalam kumpulan, menghubungkan pengalaman dengan penemuan baharu, mendapatkan pengetahuan baharu serta mendapatkan hubung kait antara peristiwa atau objek. Penggunaan pendekatan isu sosiosaintifik berbantukan peta pemikiran membantu meningkatkan tahap pemikiran sains keusahawanan pelajar kerana perbincangan isu sosiosaintifik yang dilakukan dan dizahirkan atas peta pemikiran dapat memberi pemahaman yang jelas kepada pelajar tentang apa yang perlu diperhatikan dan mencari jawapan dengan mudah terhadap isu atau masalah yang dihadapi (Mutvei et al., 2017).

Pengintegrasian pendekatan isu sosiosaintifik bersama peta pemikiran roda juga membolehkan pelajar mudah mencatatkan sebarang idea mereka dalam kaedah yang sistematik (Bengston, 2016). Sebarang idea yang difikirkan logik dan bersesuaian dengan konstruk pemerhatian, idea baharu, inovasi, kreativiti dan nilai tentang produk ciptaan dimasukkan dalam kitaran-kitaran peta pemikiran roda. Hal ini memudahkan pelajar kerana konsep kitaran dalam roda membantu dalam pengumpulan data yang pantas dan sistematik. Impaknya, pengintegrasian PIS bersama PP nyata dapat membantu pelajar dalam menguasai kelima-lima konstruk dalam pemikiran sains keusahawanan ekoran PP roda ini mudah difahami oleh pelajar dan merangsang pemikiran sistematik mereka semasa proses sumbang saran dalam kumpulan (Krueger, 2005).

Darjah peningkatan tahap pemikiran sains keusahawanan murid dalam kelima-lima konstruk bagi kaedah PISPP berbanding kaedah KK jelas dibantu oleh pengintegrasian PIS dan PP yang sistematik. Para penyelidik (Kinslow \& Sadler, 2018; Sadler et al., 2017; Topçu et al., 2018) turut menyokong bahawa penggunaan PIS bersama PP membantu menambahkan pengetahuan saintifik murid apabila mereka meneroka isu sosiosaintifik yang diberi. Perdebatan isu sosiosaintifik yang diutarakan membawa kepada perdebatan idea yang meluaskan ilmu pengetahuan tentang sains dan implikasinya dengan masyarakat dengan mendalam untuk memastikan mereka dapat memberi keputusan yang terbaik. Rentetannya, PIS mengarah kepada pembuatan keputusan yang tepat dalam memilih idea yang terbaik untuk dikembangkan dalam produk ciptaan murid (Sadler \& Zeidler, 2005; Zeidler, 2016; Zeidler \& Nichols, 2009) dan dizahirkan dalam peta pemikiran secara sistematik (Bengston, 2016).

Pendekatan isu sosiosaintifik berbantukan peta pemikiran roda sekali lagi membuktikan bahawa pendekatan ini dapat melatih murid membuat keputusan tentang isu sosial yang melibatkan implikasi moral dalam konteks saintifik (Zeidler, Dana, \& Keefer, 2003; Zeidler et al., 2005). Penyelidik sebelumnya (Driver et al., 2000; Sadler, 2004) turut menykong bahawa isu-isu sosiosaintifik membolehkan murid mengkaji dan menghubungkan sains, kehidupan seharian dan masyarakat dalam komuniti. Hal ini selari dengan objektif pemupukan pemikiran sains keusahawanan yang mana murid yang berupaya menghubungkan sains dengan masyarakat akan dapat menghasilkan produk ciptaan yang disesuaikan dengan keperluan masyarakat dan menyelesaikan isu sosiosaintifik yang timbul dalam masyarakat.

Tambahan lagi, dapatan temu bual juga membuktikan bahawa penggunaan modul pengajaran dan pembelajaran isu sosiosaintifik berbantukan peta pemikiran roda dapat membantu pelajar dalam membuat penyusunan idea dan perkembangan idea baharu dengan lebih berkesan serta membawa kepada peningkatan ilmu STEM. Pelajar yang melalui pembelajaran menggunakan modul PISPP juga didapati lebih seronok dalam menghasilkan prototaip dan bersifat lebih ingin tahu sepanjang melalui pengalaman pembelajaran PISPP. Malahan, pelajar didapati dapat memupuk sifat membantu masyarakat masa hadapan dan sifat bekerjasama dalam pasukan. 


\section{Kesimpulan}

Kajian penyelidikan ini mengesahkan bahawa modul pengajaran dan pembelajaran PISPP yang dibangunkan mempunyai kebolehpercayaan yang boleh diterima dan kesahan kandungan yang baik. Secara keseluruhannya, modul PISPP sesuai dan berkesan untuk memupuk pemikiran sains keusahawanan dalam kalangan pelajar tahun lima. Penyelidikan ini telah mengetengahkan gabungan teori konstruktivisme, Model Pembelajaran Pemikiran Sains Keusahawanan, Model Pendekatan Isu Sosiosaintifik, peta pemikiran roda, Model Pengintegrasian Swartz dan Park serta model reka bentuk instruksional ADDIE dalam membangunkan modul pengajaran dan pembelajaran isu sosiosaintifik berbantukan peta pemikiran roda yang sah, boleh dipercayai, sesuai dan berkesan dalam memupuk pemikiran sains keusahawanan dalam pendidikan STEM.

Penyelidikan ini juga menunjukkan bahawa pendekatan pelbagai disiplin yang dirancang dengan teliti untuk pengajaran PISPP membolehkan pelajar membincangkan isu sosiosaintifik dan menghasilkan prototaip bagi menyelesaikan isu sosiosaintifik yang diutarakan dengan berbantukan kitaran-kitaran dalam peta pemikiran roda. Impaknya, pelajar bukan sahaja dapat meningkatkan tahap pemikiran sains keusahawanan, malah pengetahuan STEM, perkembangan idea, perasaan seronok serta sifat bekerjasama dalam kalangan pelajar dapat ditingkatkan.

\section{Penghargaan}

Pengkaji ingin merakamkan penghargaan kepada Universiti Malaysia Sabah, Sabah, Malaysia yang telah membiayai kajian ini di bawah No. Geran SDN0005-2019.

\section{Rujukan}

Ahmad, J., \& Siew, N. M. (2021). Development of a children entrepreneurial science thinking test for STEM education. Journal of Baltic Science Education, 20(4), 528-545.

Ambo, N. (2019). Kesan pembelajaran sains berasaskan projek dan pendekatan STEM terhadap lima dimensi sifat kreativiti saintifik murid tahun lima. [Tesis Doktor Falsafah, Universiti Malaysia Sabah].

Bacigalupo, M., Kampylis, P., Punie, Y., \& Van den Brande, G. (2016). EntreComp: The entrepreneurship competence framework. Publications Office of the European Union. https://doi.org/10.2791/593884

Bahagian Pembangunan Kurikulum. (2019). Dokumen standard kurikulum dan pentaksiran sains tahun 5. Kementerian Pendidikan Malaysia.

Bengston, D. N. (2016). The futures wheel: A method for exploring the implications of socialecological change. Society and Natural Resources, 29(3), 374-379. https://doi.org/10.1080/08941920.2015.1054980

Birmingham, D., \& Barton, A. C. (2014). Putting on a green carnival: Youth taking educated action on socioscientific issues. Journal of Research in Science Teaching, 51(3), 286-314. https://doi.org/10.1002/tea.21127

Bloom, B. S. (1956). Taxonomy of educational objectives, Handbook 1: Cognitive domain (2nd ed.). David McKay Company. https://doi.org/10.1300/J104v03n01_03

Branch, R. M. (2010). Instructional design: The ADDIE approach. Springer. https://doi.org/10.4135/9781412958806.n258

Braun, V., \& Clarke, V. (2006). Using thematic analysis in psychology. Qualitative Research in Psychology, 3(77), 77-101.

Carlton, D. J., Kicklighter, J. R., Jonnalagadda, S. S., \& Shoffner, M. B. (2000). Design develop and formative evaluation for adult program. Journal of The American Dietetic Association, 100(5), $555-563$.

Chua, Y. P. (2011). Kaedah dan statistik penyelidikan: Kaedah penyelidikan. Mcgraw-Hill Education.

Cohen, L., Manion, L., \& Morrison, K. (2018). Research methods in education. Routledge.

Cohen, R. J., \& Swedlik, M. E. 2018. Psychological testing and assessment: An introduction to tests 
and measurement. Guidebook for Clinical Psychology Interns (9th ed.). McGraw-Hill Education.

Darmaji, Kurniawan, D. A., \& Irdianti. (2019). Physics education students' science process skills. International Journal of Evaluation and Research in Education, 8(2), 293-298. https://doi.org/10.11591/ijere.v8i2.28646

Driver, R., Newton, P., \& Osborne, J. (2000). Establishing the norms of scientific argumentation in classrooms. Science Education, 84(3), 287. https://doi.org/10.1002/(sici)1098$237 x(200005) 84: 3<287:$ :aid-sce1>3.3.co;2-1

Fereday, J., \& Muir-Cochrane, E. (2006). Demonstrating rigor using thematic analysis: A hybrid approach of inductive and deductive coding and theme Development. Interdisciplinary Journal of Qualitative Methods, 5(1), 80-92. https://doi.org/10.1177/160940690600500107

Gay, L. R., \& Airasian, P. W. (2003). Educational research: Competencies or analysis and applications. Prentice Hall.

Glenn, J. (1972). Futurizing teaching vs. futures courses. Social Science Record, 9(3), 26-29.

Hair, J. F., Black, W. C., Babin, B. J., Anderson, R. E., \& Tatham, R. L. (2006). Multivariate data analysis (6th ed.). Prentice Hall.

Ho, H.-C., Wang, C.-C., \& Cheng, Y.-Y. (2013). Analysis of the scientific imagination process. Thinking Skills and Creativity, 10, 68-78.

Jones, M. G., \& Brader-Araje, L. (2002). The impact of constructivism on education: Language, discourse, and meaning. American Communication Journal, 5(3), 1-10.

Junus, I. S., Santoso, H. B., Isal, R. Y. K., \& Utomo, A. Y. (2021). Usability evaluation of the student centered e-learning environment. International Review of Research in Open and Distributed Learning, 16(4), 62-82. https://doi.org/https://doi.org/10.19173/irrodl.v16i4.2175

Karlsson, C., Rickardsson, J., \& Wincent, J. (2021). Diversity, innovation and entrepreneurship: where are we and where should we go in future studies? In Small Business Economics (Vol. 56, Issue 2, pp. 759-772). https://doi.org/10.1007/s11187-019-00267-1

Khishfe, R., Alshaya, F. S., BouJaoude, S., Mansour, N., \& Alrudiyan, K. I. (2017). Students' understandings of nature of science and their arguments in the context of four socio-scientific issues. International Journal of Science Education, 39(3), 299-334. https://doi.org/10.1080/09500693.2017.1280741

Kinslow, A. T., \& Sadler, T. D. (2018). Making science relevant: Using socio-scientific issues to foster critical thinking. The Science Teacher, 86(1), 40-45. www.nsta.org/highschool

Mutvei, A., Lönn, M., \& Mattsson, J.-E. (2017). Development of observation skills in science education for enhanced understanding. ESERA 2017 (European Science Education Research Association), Dublin, August 21-25, 2017.

Nam, Y., \& Chen, Y. C. (2017). Promoting argumentative practice in socio-scientific issues through a science inquiry activity. Eurasia Journal of Mathematics, Science and Technology Education, 13(7), 3431-3461. https://doi.org/10.12973/eurasia.2017.00737a

Noah, S.M., \& Ahmad, J. (2005). Module development: How to develop practice module and academic module. Univerisiti Putra Malaysia.

Buang, N. A., Halim, L., \& Subahan, T. M. M. (2009). Understanding the thinking of scientists entrepreneurs: Implications for science education in Malaysia. Journal of Turkish Science Education, 6(2), 3-11.

Owens, D. C., Sadler, T. D., \& Zeidler, D. L. (2017). Controversial issues in the science classroom. Phi Delta Kappan, 99(4), 45-49. https://doi.org/10.1177/0031721717745544

Pascual-Leone, J., \& Johnson, J. (2005). A dialectical constructivist view of developmental intelligence. Handbook of Understanding and Measuring Intelligence, 177-201.

Piaget, J. (1976). Piaget's theory. In Piaget and His School (pp. 11-23). https://doi.org/10.1007/978-3642-46323-5_2

Rahman, M.S.A. (2020). Pendekatan berasaskan sosio-saintifik berbantukan peta pemikiran masa hadapan terhadap lima konstruk pemikiran masa hadapan pelajar. [Tesis Doktor Falsafah, Universiti Malaysia Sabah].

Saavedra, A. R., \& Opfer, V. D. (2012). Learning 21st-century skills requires 21 st-century teaching. Phi Delta Kappan, 94(2), 8-13. https://doi.org/10.1177/003172171209400203

Sadler, T. D. (2004). Informal reasoning regarding socioscientific issues: A critical review of research. Journal of Research in Science Teaching, 41(5), 513-536. https://doi.org/10.1002/tea.20009 
Sadler, T. D., \& Zeidler, D. L. (2005). The significance of content knowledge for informal reasoning regarding socioscientific issues: Applying genetics knowledge to genetic engineering issues. Science Education, 89(1), 71-93. https://doi.org/10.1002/sce.20023

Sadler, T. D., Foulk, J. A., \& Friedrichsen, P. J. (2017). Evolution of a model for socio-scientific issue teaching and learning. International Journal of Education in Mathematics Science and Technology, 5(2), 75-87.

Sekaran, U., \& Bougie, R. (2010). Research methods for business: A skill building approach (5th ed.). John Willey \& Sons Ltd.

Sjøberg, S. (2007). Contructivism and learning. In International Encyclopaedia of Education (3rd ed.). Elsevier. https://doi.org/10.1134/S1061933X16060144

Swartz, R. J., \& Parks, S. (1994). Infusing the teaching of critical and creative thinking into content instruction: A lesson design handbook for the elementary grades. Critical Thinking Books and Software.

Swartz, R. J., \& Parks, S. 1994. Infusing the teaching of critical and creative thinking into content instruction: A lesson design handbook for the elementary grades. Critical Thinking Books and Software.

Syukri, M., Halim, L., \& Meerah., T.S.M. (2013). Pendidikan STEM dalam entrepreneurial science thinking "ESciT": Satu perkongsian pengalaman dari UKM untuk Aceh. Aceh Development International Conference 2013, 105-112.

Taherdoost, H. 2016. Validity and reliability of the research instrument; How to test the validation of a questionnaire / survey in a research. International Journal of Academic Research in Management, 5(3), 28-36.

Topçu, M. S., Foulk, J. A., Sadler, T. D., Pitiporntapin, S., \& Atabey, N. (2018). The classroom observation protocol for socioscientific issue-based instruction: development and implementation of a new research tool. Research in Science \& Technological Education, 36(3), 302-323. https://doi.org/10.1080/02635143.2017.1399353

Vygotsky, L. (1978). Mind in society: The development of higher psychological processes. Harvard University Press. https://doi.org/10.1016/S0140-6736(10)60669-1

Zeidler, D. L. (2016). STEM education: A deficit framework for the twenty first century? A sociocultural socioscientific response. Cultural Studies of Science Education, 11(1), 11-26. https://doi.org/10.1007/s11422-014-9578-z

Zeidler, D. L., \& Nichols, B. H. (2009). Socioscientific issues: Theory and practice. Journal of Elementary Science Education, 21(2), 49-58. https://doi.org/10.1007/bf03173684

Zeidler, D. L., Sadler, T. D., Applebaum, S., \& Callahan, B. E. (2009). Advancing reflective judgment through socioscientific issues. Journal of Research in Science Teaching, 46(1), 74-101. https://doi.org/10.1002/tea.20281

Zeidler, D. L., Sadler, T. D., Simmons, M. L., \& Howes, E. V. (2005). Beyond STS: A research-based framework for socioscientific issues education. Science Education, 89(3), 357-377. https://doi.org/10.1002/sce.20048

Zeidler, Dana L; Keefer, M. (2003). The role of moral reasoning on socioscientific issues and discourse in science education. Kluwer Academic Pubishers. 